\title{
Structural characterization of Escherichia coli sialic acid synthase
}

\author{
Tzann-Shun Hwang, ${ }^{\text {a,b }}$ Chih-Hung Hung, ${ }^{\text {a }}$ Chin-Fen Teo, ${ }^{a}$ Guan-Ting Chen, ${ }^{\text {a,b }}$ \\ Lee-Shang Chang, ${ }^{a}$ Sung-Fang Chen, ${ }^{c} \mathrm{Yu}-\mathrm{Ju}$ Chen, ${ }^{\mathrm{c}, *}$ and Chun-Hung Lin ${ }^{\mathrm{a}, \mathrm{b}, *}$ \\ a Institute of Biological Chemistry, Academia Sinica, No. 128 Academia Road Sec. 2, Nan-Kang, Taipei 11529, Taiwan \\ ${ }^{\mathrm{b}}$ Institute of Biochemical Sciences, National Taiwan University, Taipei 10617, Taiwan \\ ${ }^{\mathrm{c}}$ Institute of Chemistry, Academia Sinica, Taipei 11529, Taiwan
}

Received 21 May 2002

\begin{abstract}
Sialic acid synthase encoded by the neuB gene of Escherichia coli catalyzes the condensation of $N$-acetylmannosamine and phosphoenolpyruvate to form $\mathrm{N}$-acetylneuraminic acid. This report demonstrates the first structural information on sialic acid synthase by CD, MALDI-TOF, and chemical cross-linking studies. Also, a specific cleavage by endogenous protease(s) has been identified at Lys ${ }^{280}$ of the enzyme $(40 \mathrm{kDa})$ by LC-MS and N-terminal sequencing analyses. The cleavage results in the formation of two inactive fragments of 33 and $7 \mathrm{kDa}$. The structural analysis indicates that the fragmentation is associated with a significant change of the enzyme from a tetrameric to trimeric form, and alterations in both secondary and native quaternary structures. (C) 2002 Elsevier Science (USA). All rights reserved.
\end{abstract}

Keywords: Sialic acid synthase; $N$-Acetylneuraminic acid (NeuAc); Circular dichroism (CD); Matrix-assisted laser desorption (MALDI)/ionizationtime-of-flight (TOF); Subunit cross-linking

Sialic acids, a family of 3-deoxy-2-keto nine carbon sugars, are located in the non-reducing terminal ends of cell-surface glycoconjugates of viruses, mammalian cells, and some bacteria. These high-carbon sugar residues play an indispensable role in a myriad of biological activities, such as the events of development, activation, aging, and oncogenesis [1,2], cell adhesion among leukocytes, platelets, and endothelial cells [3-5], and prevention of the degradation of cell-surface carbohydrates $[6,7]$.

Sialylated capsular polysaccharides function as virulent factors of bacteria encompassing the group B Streptococci, Neisseria meningitidis and Escherichia coli $\mathrm{K} 1$, even though the natural distribution of sialic acids is less common in bacteria [8-10]. The genes for the biosynthesis and transport of the K1 capsular components have been characterized and located in the $17 \mathrm{~kb} k p s$ gene cluster, which is composed of three functional regions [11-13]. In E. coli K1, the genes in region 2, identified as neuDBACES genes, are responsible for the synthesis,

\footnotetext{
${ }^{*}$ Corresponding authors. Fax: +886-2-2651-4705.

E-mail address: chunhung@gate.sinica.edu.tw (C.-H. Lin).
}

activation, and polymerization of sialic acid [11]. Two genes, neuB and neuC, are required for the production of sialic acid. The latter is necessary for the conversion of UDP $N$-acetylglucosamine (UDP-GlcNAc) to $N$-acetylmannosamine (ManNAc) [14]. The former encodes the enzyme, sialic acid synthase, catalyzing the condensation of ManNAc with PEP to give $N$-acetylneuraminic acid (NeuAc) [15]. In contrast, a three-enzyme pathway has been identified to convert ManNAc to NeuAc in mammalian cells via the formation of $N$-acetylmannosamine 6-phosphate (ManNAc-6-P) and $N$-acetylneuraminic acid 9-phosphate (NeuAc-9-P) [16-19]. The human NeuAc-9-P synthase and E. coli NeuB accept different sugar substrates (ManNAc-6-P vs. ManNAc) and share $36 \%$ sequence identity [20]. In addition, sialic acid aldolase catalyzes the reversible formation of NeuAc from pyruvate and ManNAc, yet favoring the reaction direction of degradation [21]. It is intriguing to understand how NeuB is related to the human NeuAc-9-P synthase and E. coli sialic acid aldolase at a structural level. Nevertheless, most studies of sialic acid synthase have been limited to the gene location and detection of corresponding protein activity. 
In this report, we present the first structural studies of sialic acid synthase including circular dichroism (CD) and matrix-assisted laser desorption/ionization (MALDI)-time-of-flight (TOF) mass spectrometry coupled with chemical cross-linking experiments. The result is consistent with those of $E$. coli sialic acid aldolase and $E$. coli 3-deoxy-D-manno-octulosonate 8-phosphate (KDO8 -P) synthase. The latter enzyme catalyzes a reaction similar to that of NeuB, the formation of KDO-8-P from arabinose 5-phosphate and PEP. Furthermore, we have identified a specific site of cleavage on the native $40 \mathrm{kDa}$ enzyme, resulting in the formation of 33 and $7 \mathrm{kDa}$ fragments with no activity. The formation of a smaller molecular weight $(33 \mathrm{kDa})$ than that of the desired protein was observed in the SDS-PAGE analysis by Silver et al. $[15,22]$ and thus proposed to arise from the degradation of the neuB gene product without further characterization [15]. Our structural analysis indicated that the cleavage was associated with a significant change in secondary structure, as well as an alteration of the native quaternary state.

\section{Materials and methods}

Materials. All the chemicals and reagents were purchased from Sigma (St. Louis, MO), Roche (Mannheim, Germany), and Merck (Darmstadt, Germany). Medium components were from BectonDickinson (Sparks, MD). Restriction enzymes were purchased from New England Biolabs (Beverly, MA). All the primers were synthesized by Quality System Co. (Taipei, Taiwan).

$D N A$ manipulation and protein purification. The gene of E. coli sialic acid synthase $(n e u B)$ was cloned from $E$. coli $\mathrm{K} 1$ genomic DNA. According to the reported sequence (GenBank Accession No. U05248) [15], the plasmid ( $\mathrm{pHis}^{6}-\mathrm{NeuB}$ ) was constructed to overproduce sialic acid synthase with a hexahistidine tag in the $\mathrm{N}$-terminus $\left(\mathrm{His}^{6}-\mathrm{NeuB}\right)$ by using primer 1 (GCGCG GATCC GACGA CGACG ACAAG ATGAG TAATA TATAT ATCGT TGC, including a Bam HI restriction site and upstream sequence of $n e u B$ ) and primer 2 (GCGCC TGCAG TTACG ATTCC CCCTG ATTTT TG, including a Pst

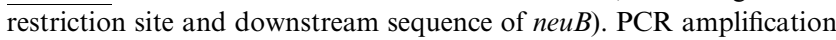
was performed according to the standard procedure [23]. Analogously, the plasmid $\mathrm{pHis}^{6}-\mathrm{NeuB} 33 \mathrm{k}$ was constructed to overproduce the $33 \mathrm{kDa}$ fragment of sialic acid synthase with a hexahistidine tag in the N-terminus ( $\mathrm{His}^{6}-\mathrm{NeuB33 \textrm {k }}$ ) by using primers 1 and 3 (GCGCC TGCAG TTATT TATTC TTCCT TTCTG, corresponding to nucleotides $824-840$ of $n e u B$ with a PstI site for cloning). The plasmid pNeuB-His ${ }^{6}$ was constructed to overproduce sialic acid synthase with a hexahistidine tag in the $\mathrm{C}$-terminus (NeuB-His ${ }^{6}$ ) by using primer 4 (GGAAC ATATG AGTAA TATAT ATATC GTTGC TGAAA TTGG, containing an $N d e$ I restriction site and upstream sequence of $n e u B$ ) and primer 5 (GTTCC TCGAG TTCCC CCTGA TTTTT G, containing an $\mathrm{XhoI}$ restriction site and downstream sequence of neuB). The plasmid pNeuB33k-His ${ }^{6}$ was constructed to overproduce the $33 \mathrm{kDa}$ fragment of sialic acid synthase with a hexahistidine tag in the C-terminus (NeuB33k-His ${ }^{6}$ ) by using primers 4 and 6 (CTTTC TTGCC TCGAG TTTAT TCTTC CTTTC, corresponding to nucleotides $\overline{826-840 \text { of }} n e u B$ with an XhoI site for cloning). After amplification, the four PCR products were individually digested with desired restriction enzymes and ligated with a similarly digested vector (pQE30 or pET21b). The ligated plasmid was transformed into E. coli M15 or E. coli BL21 (DE3) for expression.
The clones for expression were cultured in LB broth containing $100 \mu \mathrm{g} / \mathrm{ml}$ ampicillin at $37^{\circ} \mathrm{C}$ until $\mathrm{A}_{600}$ reached 1.0. Expression was induced by the addition of $1 \mathrm{mM}$ isopropyl-1-thio- $\beta$-D-galactopyranoside (IPTG) for $3 \mathrm{~h}$, after which the culture was harvested by centrifugation and lysed by the following procedure. The cell pellets were resuspended in $10 \mathrm{ml}$ lysis buffer $\left(50 \mathrm{mM} \mathrm{NaH} \mathrm{PO}_{4}, 300 \mathrm{mM}\right.$ $\mathrm{NaCl}, 10 \mathrm{mM}$ imidazole, $\mathrm{pH} 8.0$ ), disrupted by sonicator, and centrifuged at $15,000 \mathrm{~g}$. The supernatant was applied to a HiTrap chelating high performance (HP) column (Pharmacia) according to the manual instruction. By the thiobarbituric acid assay [24] and SDS-PAGE, the desired fractions were pooled and desalted to make a final concentration of $\mathrm{NaCl}$ less than $50 \mathrm{mM}$. The pooled protein was applied to a HiTrap Q-Sepharose HP column (Pharmacia), which had been preequilibrated with $50 \mathrm{mM}$ Tris buffer $(\mathrm{pH} 8.0)$. After loading of the sample, the column was washed with the same buffer and then eluted with a linear gradient of $0-500 \mathrm{mM} \mathrm{NaCl}$ in $50 \mathrm{mM}$ Tris buffer, $\mathrm{pH} 8.0$. The desired fractions were pooled and dialyzed in $50 \mathrm{mM}$ Tris buffer $(\mathrm{pH} 8.0)$ to yield the protein with homogeneity of more than $97 \%$.

LC-MS analysis. The analysis was performed on Agilent (Palo Alto, CA) 1100 LC system coupled with Finnigan (San Jose, CA) LCQ electrospray ionization (ESI) ion-trap mass spectrometer. The mixture containing $\mathrm{His}^{6}$-NeuB and degradation products was infused into reversed-phase high performance liquid chromatography (RP-HPLC) in a Vydac (Hesperia, CA) $1.0 \times 150 \mathrm{~mm} \mathrm{C}_{18}$ column. Ten $\mu$ protein sample $(50 \mu \mathrm{g})$ was injected to LC for a typical measurement. The eluent was composed of solvent A ( $0.1 \%$ trifluoroacetic acid (TFA) in water) and solvent $\mathrm{B}(0.1 \%$ TFA in acetonitrile). The gradients were 0 $60 \mathrm{~min}, 2-60 \%$ solvent $\mathrm{B}$ at a flow rate of $50 \mu \mathrm{l} / \mathrm{min}$. The ESI-MS was operated in positive-ion mode with an $\mathrm{m} / \mathrm{e}$ range from 50 to 2000 and electrospray voltage was set at $4.5 \mathrm{kV}$. The sheath nitrogen gas flow rate was controlled at $60 \mathrm{~L} / \mathrm{h}$ and capillary temperature was kept at $200^{\circ} \mathrm{C}$.

Circular dichroism studies. The CD spectra were obtained on a Jasco J-715 automatic recording spectropolarimeter at $25^{\circ} \mathrm{C}$. The proteins were dissolved in $0.05 \mathrm{M}$ Tris buffer, $\mathrm{pH} 8.0$, at a concentration of $0.05-0.50 \mathrm{mg} / \mathrm{ml}$. The spectra were recorded from 190 to $260 \mathrm{~nm}$ at a scanning rate of $50 \mathrm{~nm} / \mathrm{min}$ with a wavelength step of $0.5 \mathrm{~nm}$. After background subtraction, the $\mathrm{CD}$ data were converted from $\mathrm{CD}$ signal into mean residue ellipticity (degrees $\mathrm{cm}^{2} \mathrm{dmol}^{-1}$ ). Analysis of $\mathrm{CD}$ spectrum in the far-UV region in terms of the fractions of the structural elements, i.e., $\alpha$-helix, $\beta$-strand, and unordered form, was carried out according to the SELCON3 method developed by Sreerama and co-workers $[25,26]$ to find the best estimate for the percentage contribution of each structural element in the native protein and its fragment.

Gel filtration to measure molecular weight. The enzyme solution (of NeuB-His ${ }^{6}$ or NeuB33k-His ${ }^{6}$ ) was applied into a column of Superose 12 HR 10/30 (Amersham Pharmacia), equilibrated with $50 \mathrm{mM}$ Tris buffer (pH 8.0) containing $500 \mathrm{mM} \mathrm{NaCl}$. Bio-Rad Gel Filtration Calibration Kit (Hercules, CA) was used as molecular weight standards.

MALDI sample preparation and spectra acquisition. Sialic acid synthase and the $33 \mathrm{kDa}$ fragment (NeuB-His ${ }^{6}$ and NeuB33k-His ${ }^{6}$ ) were prepared at a concentration of $0.1 \mathrm{mg} / \mathrm{ml}$. The matrix solution was freshly prepared before use; sinapinic acid (SA) was dissolved in $30 \%$ acetonitrile (in water) at a concentration of $10 \mathrm{mg} / \mathrm{ml}$ in the presence of $0.1 \%$ TFA. The sample/matrix mixture of $2 \mu \mathrm{l}$ was loaded onto a MALDI sample plate and allowed to air-dry under ambient temperature for mass spectrometric analysis. All mass spectrometric experiments were performed on a Voyager-DE PRO MALDI-TOF mass spectrometer (PerSeptive Biosystems, Framingham, MA) equipped with a nitrogen laser operating at $337 \mathrm{~nm}$ for desorption/ ionization. The instrument was operated in the delayed extraction linear mode with a delay time of $750-1000 \mathrm{~ns}$. Accelerating voltage was set at $25 \mathrm{kV}$ and the grid voltage was $90-93 \%$ of the acceleration voltage. Each set of experiments was calibrated externally using bovine serum albumin (BSA). 
Subunit cross-linking experiments. The studies were performed according to the method of Davis and co-workers [27,28] using dimethyl suberimidate (DMS). The protein (NeuB-His ${ }^{6}$ or NeuB33k-His ${ }^{6}$ ) and cross-linking agent were dissolved separately in $0.2 \mathrm{M}$ triethanolamine $-\mathrm{HCl}(\mathrm{pH} 8.5)$ to give the protein of $0.2-6.0 \mathrm{mg} / \mathrm{ml}$ and DMS of $0.5-10 \mathrm{mg} / \mathrm{ml}$, respectively. The two solutions were mixed together immediately after they had been prepared. The reaction was carried out at $25^{\circ} \mathrm{C}$ for 1,2 , and $3 \mathrm{~h}$, stopped by adding $1 \%$ SDS and $0.1 \%$ 2-mercaptoethanol, and followed by heating at $100^{\circ} \mathrm{C}$. Reaction products were examined by SDS-PAGE analysis.

\section{Results and discussion}

\section{Identification of the cleavage site and activity loss of the cleaved fragment}

The neuB gene from $E$. coli $\mathrm{K} 1$, previously reported by Silver et al. [15,22], was cloned and expressed in $E$. coli. The protein containing a hexahistidine tag at the $N$ terminus was designated as $\mathrm{His}^{6}-\mathrm{NeuB}$. The purification by nickel affinity chromatography generated two separate bands as detected in SDS-PAGE, which was consistent with the previous observation by Silver's group [15]. The upper band corresponded with the desired protein of molecular mass $40 \mathrm{kDa}$. Nevertheless, efforts to apply other chromatographic procedures including Mono Q and DEAE-Sepharose anion exchange, and Superdex 75 gel filtration all failed in the removal of the smaller protein component from $\mathrm{His}^{6}-\mathrm{NeuB}$. However, Western blot with $6 \times$ His antibodies reacted positively with both protein components. An N-terminal sequencing analysis for both proteins showed that the first 20 amino acid residues are identical. It pointed to the fact that the smaller protein fragment should come from the cleavage of $\mathrm{His}^{6}-\mathrm{NeuB}$.

After the purification by a nickel affinity column, the aforementioned protein mixture was subjected to LCMS analysis. The result indicated the molecular mass of the major protein to be $40,538 \mathrm{Da}$, consistent with the value of the native protein calculated from its amino acid sequence, and that of the minor component 33,053 Da (Fig. 1A). Meanwhile, a smaller protein with a molecular mass of $7502 \mathrm{Da}$ was detected to exist in the mixture during the analysis (Fig. 1B). N-terminal sequencing for the $7 \mathrm{kDa}$ protein showed the first ten residues to be IVARKSIIAK, which corresponds to the segment of $\mathrm{Ile}^{281}-\mathrm{Lys}^{290}$ of NeuB sequence. The molecular mass of the segment from $\mathrm{Ile}^{281}$ to $\mathrm{Glu}^{346}$ (the Cterminal 66 amino acids of NeuB) was calculated to be about $7.5 \mathrm{kDa}$, close to that of the smaller fragment described. Therefore, the sum of two fragments of 33,053 and $7502 \mathrm{Da}$ was equal to $40,555 \mathrm{Da}$, only one Dalton difference from the expected value of 40,556 (40,538 Da plus $18 \mathrm{Da}$ of a water molecule). As a consequence, it clearly indicated that sialic acid synthase might have been processed through a proteolytic cleav- age at Lys $^{280}$ to give two fragments of 33 and $7 \mathrm{kDa}$. Previously, the presence of a $33 \mathrm{kDa}$ fragment detected was proposed to arise from the degradation of the neuB gene product without detailed characterization [15].

To characterize the full-length enzyme and $33 \mathrm{kDa}$ fragment, and to avoid difficulty of their separation, the two proteins were thus prepared with a hexahistidine tag linked at their $\mathrm{C}$-termini. The protein corresponding to the whole NeuB sequence was named as NeuB-His ${ }^{6}$ and the other containing the $\mathrm{N}$-terminal 280 residues as NeuB33k-His ${ }^{6}$. Although the purification of NeuB-His ${ }^{6}$ from nickel affinity chromatography resulted in the mixture of the tagged full-length protein and $7 \mathrm{kDa}$ fragment, the apparent size difference of these two polypeptides allowed the acquisition of pure NeuB-His ${ }^{6}$ easily. On the basis of the thiobarbituric acid assay [24], the specific activity of NeuB-His ${ }^{6}$ was determined to be $37 \mathrm{nmol} / \mathrm{min} / \mathrm{mg}$. In contrast, NeuB33k-His ${ }^{6}$ was shown to possess no activity under the same conditions. $\mathrm{His}^{6}{ }^{6}$ NeuB33k, another $33 \mathrm{kDa}$ protein having a hexahistidine tag at $\mathrm{N}$-terminus, was prepared and also found to be catalytically inactive (data not shown). Except for $\mathrm{His}^{6}-\mathrm{NeuB}$, all the proteins were purified to give an apparent homogeneity greater than $97 \%$ before the activity assay. The lower activity of $\mathrm{His}^{6}-\mathrm{NeuB}(26 \mathrm{nmol} /$ $\mathrm{min} / \mathrm{mg}$ ) was thus due to the existence of an inseparable and inactive $33 \mathrm{kDa}$ fragment.

\section{Structural basis to account for activity loss}

Although sialic acid synthase and sialic acid 9-phosphate synthase have been identified by their existence at protein level in different species $[15,20,22]$, the structural features have never been explored. To understand the structural basis underlying the activity loss, the fulllength protein (NeuB-His ${ }^{6}$ ) and $33 \mathrm{kDa}$ fragment (NeuB33k-His ${ }^{6}$ ) were compared in their secondary structure by CD spectroscopy. As demonstrated in Fig. 2 , the CD spectra of sialic acid synthase, especially in the far-UV region, increased in intensity when the C-terminal part of the protein was truncated. Estimation of protein secondary structure fractions from CD spectra by the SELCON3 method $[25,26]$ indicated a gain of $9.2 \% \alpha$-helix with a concomitant loss of $9.7 \% \beta$-strand upon fragmentation.

Furthermore, sialic acid synthase $\left(\mathrm{NeuB}-\mathrm{His}^{6}\right)$ was eluted from a calibrated gel-filtration column as a single and symmetrical peak, corresponding to a mass of $135 \mathrm{kDa}$, which is between the masses of trimer and tetramer. The same gel filtration study on the $33 \mathrm{kDa}$ fragment (NeuB33k-His ${ }^{6}$ ) revealed that a peak corresponding to a mass of trimer was observed. Nevertheless, to verify the existence of a multimeric form, full-length sialic acid synthase $\left(\mathrm{NeuB}-\mathrm{His}^{6}\right)$ and its fragment $\left(\right.$ NeuB33k-His ${ }^{6}$ ) were separately subjected to MALDITOF-MS. MALDI mass spectrometry has been applied 
A

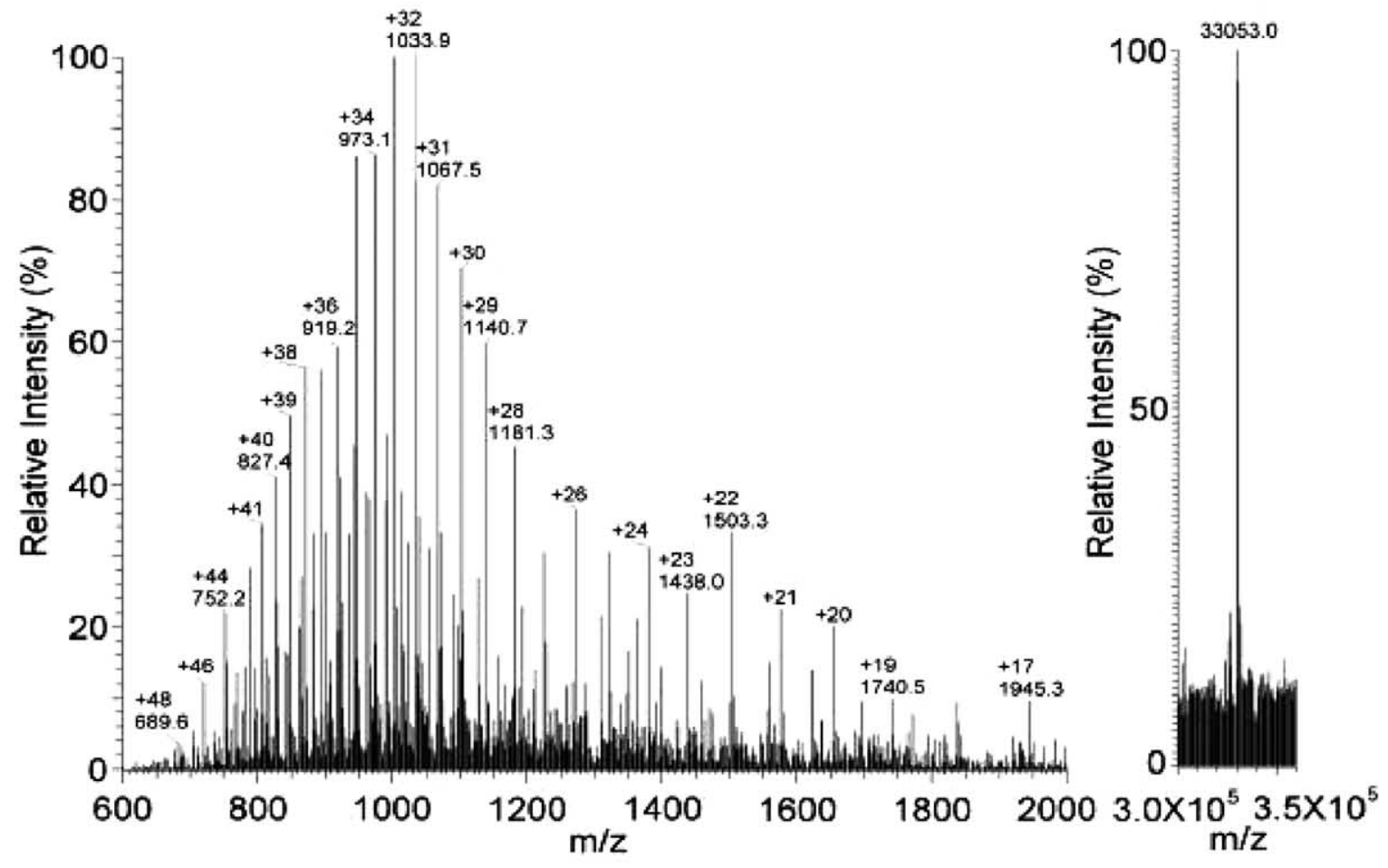

B

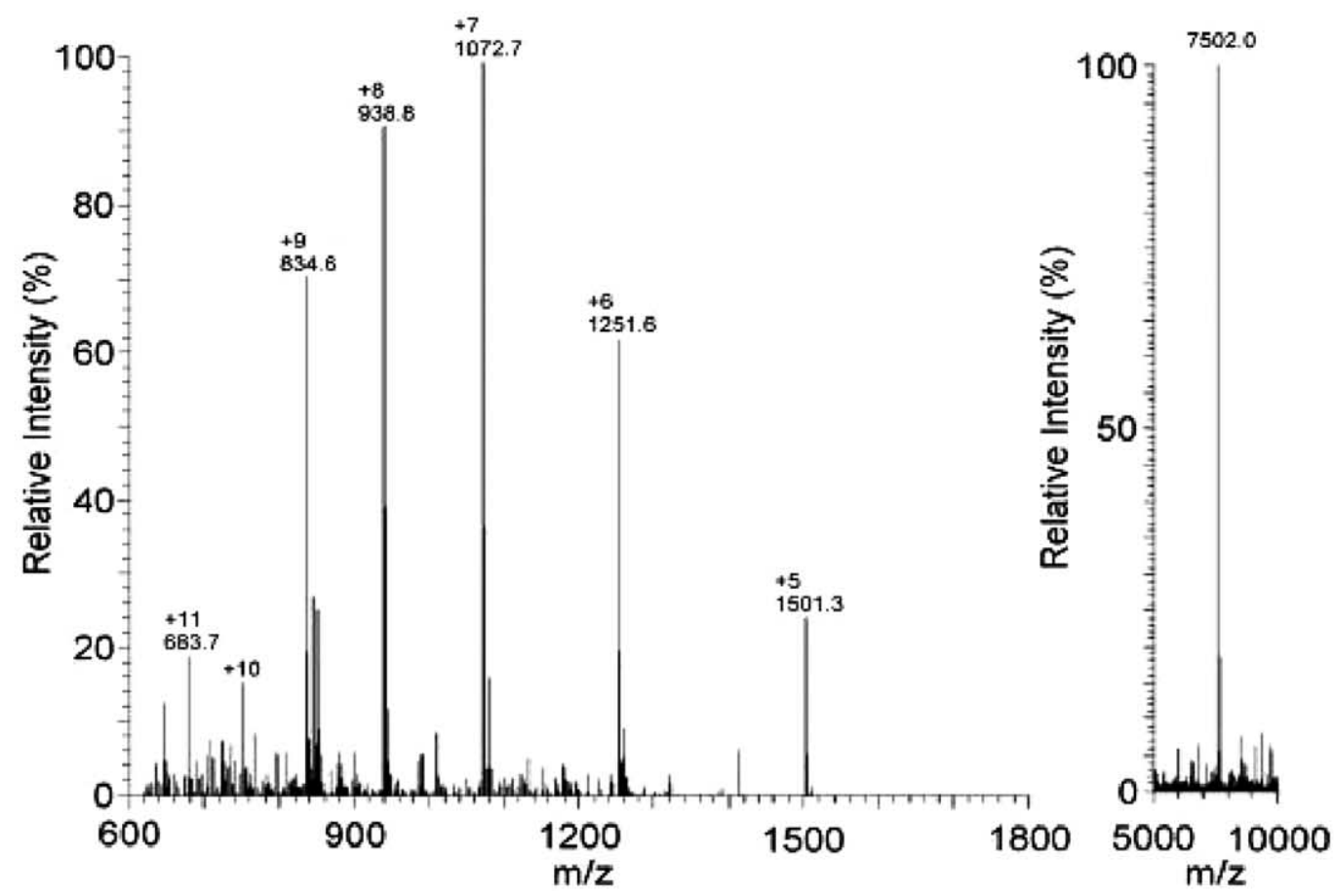

Fig. 1. Mass spectra of the 33 and $7 \mathrm{kDa}$ fragments. The mixture of sialic acid synthase $\left(\mathrm{His}^{6}-\mathrm{NeuB}\right)$ and $33 \mathrm{kDa}$ fragment was subjected to LC-MS analysis, which was carried out according to the described procedures in Materials and methods. A signal corresponding to the $7 \mathrm{kDa}$ fragment was found in LC and identified its molecular mass by subsequent mass analysis. (A) ESI spectra (left) and deconvoluted molecular weight of the $33 \mathrm{kDa}$ fragment (right). (B) ESI spectra (left) and deconvoluted molecular weight of the $7 \mathrm{kDa}$ fragment (right). 


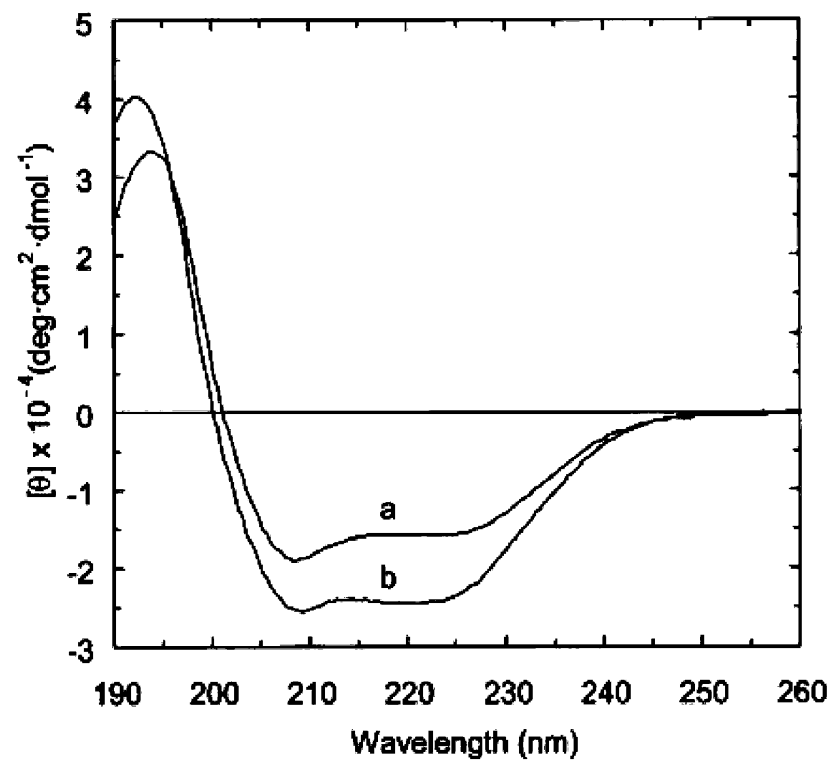

Fig. 2. CD spectra of sialic acid synthase and the $33 \mathrm{kDa}$ fragment in the far-UV region. The CD spectra were obtained on a Jasco J-715 spectropolarimeter at $25^{\circ} \mathrm{C}$. Protein concentrations were $0.05-0.50 \mathrm{mg} /$ $\mathrm{ml}$ (in $50 \mathrm{mM}$ Tris buffer ( $\mathrm{pH} 8.0$ ) containing $150 \mathrm{mM} \mathrm{NaF}$, and $20 \mathrm{mM} \mathrm{MgCl}_{2}$ ) in a $0.1 \mathrm{~cm}$ light path CD-cell for far-UV measurements. After background subtraction, the $\mathrm{CD}$ data were converted from CD signals into mean residue ellipticity (degrees $\mathrm{cm}^{2} \mathrm{dmol}^{-1}$ ). Curves $\mathrm{a}$ and $\mathrm{b}$ represent the full-length protein $\left(\mathrm{NeuB}-\mathrm{His}^{6}\right)$ and $33 \mathrm{kDa}$ fragment (NeuB33k-His$\left.{ }^{6}\right)$, respectively. It is noted that, in the peptide backbone region (205-230 nm), $\alpha$-helix content increased and $\beta$-strand decreased for $33 \mathrm{kDa}$ fragment as compared to the native enzyme.

to study non-covalent protein-protein interactions and the associated protein oligomers formed by monomeric subunits owing to its high sensitivity and capacity of determining very high molecular mass complexes [2931]. With respect to the full-length protein, the existence of a tetramer was found by the appearance of both a singly charged peak $\left(\mathrm{Q}_{40}^{+}\right)$and a doubly charged peak $\left(\mathrm{Q}_{40}^{2+}\right)$ in the MALDI spectra (Fig. 3A). The $33 \mathrm{kDa}$ fragment was observed to exist in a trimeric state under identical conditions (Fig. 3B). The result was further corroborated by the cross-linking experiments with DMS, which clearly indicated a tetrameric form for native protein and a trimer for the $33 \mathrm{kDa}$ fragment (Fig 4). Therefore, the fragmentation of sialic acid synthase generated obvious changes in the distributions of secondary structures including $\alpha$-helix and $\beta$-strand, with a concomitant transformation in quaternary structure from a tetramer to a trimer.

To understand whether the site-specific cleavage was caused by protease(s) in vivo, we incubated the $\mathrm{His}^{6}$ $\mathrm{NeuB}$ recombinant cells at $4{ }^{\circ} \mathrm{C}$ as the resting cells (to avoid the interference resulting from cell death and organelle degradation) after the IPTG induction (at $\left.A_{600}=1.0\right)$. We periodically harvested the cells for analysis of expressed products by SDS-PAGE and
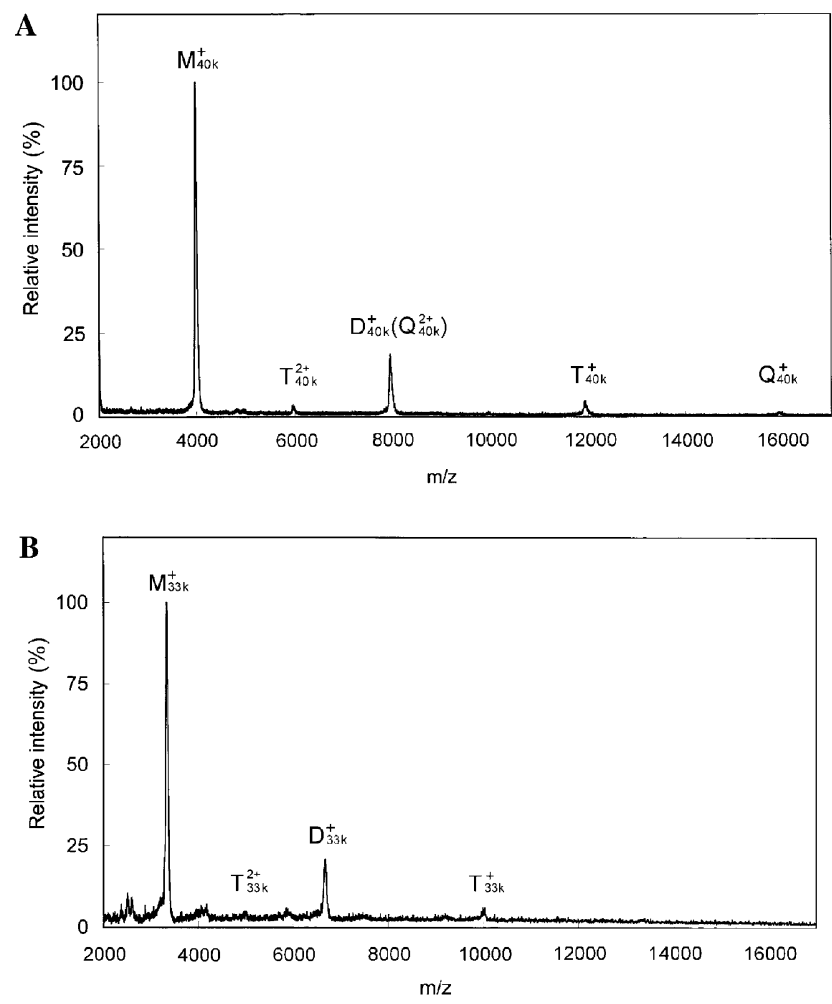

Fig. 3. MALDI-MS spectra of sialic acid synthase and the $33 \mathrm{kDa}$ fragment. The spectra were obtained by a MALDI-TOF mass spectrometer. A $1 \mu \mathrm{l}$ mixture of protein $(0.1 \mathrm{mg} / \mathrm{ml})$ and matrix solution (sinapinic acid) was mixed and deposited into a sample plate for mass spectrometric analysis. (A) Sialic acid synthase $\left(\mathrm{NeuB}-\mathrm{His}^{6}\right)$. The symbols of $\mathrm{M}_{40 \mathrm{k}}, \mathrm{D}_{40 \mathrm{k}}$, and $\mathrm{Q}_{40 \mathrm{k}}$ designate the monomer, dimer, and tetramer of the full-length enzyme, respectively. (B) Thirty-three kDa fragment $\left(\mathrm{NeuB} 33 \mathrm{k}-\mathrm{His}^{6}\right) . \mathrm{M}_{33 \mathrm{k}}, \mathrm{D}_{33 \mathrm{k}}$, and $\mathrm{T}_{33 \mathrm{k}}$ represent the monomer, dimer, and trimer of the $33 \mathrm{kDa}$ fragment, respectively.

carried out further identification by Western blotting with anti $6 \times$ His antibodies. We found that the band of the $33 \mathrm{kDa}$ fragment appeared and then increased gradually with incubation time. It is of interest to know that the enzyme was cleaved by proteases at specific single site to produce a stable fragment, instead of successive degradation. Additionally, it is noted that once the full-length enzyme (NeuB-His ${ }^{6}$ ) has been purified from the recombinant cells, it is not susceptible to cleavage.

\section{Comparison of NeuB with other known structures}

The crystal structures of $E$. coli sialic acid aldolase [32] and E. coli KDO-8-P synthase [33] have been determined. Although there is no obvious sequence similarity among the three E. coli enzymes-sialic acid synthase, sialic acid aldolase, and KDO-8-P synthase, it is a coincidence that the last two proteins are homotetramers in which each subunit consists of an $\alpha / \beta$-barrel. Further analysis of the secondary structures revealed that sialic acid synthase $(32.9 \% \alpha$-helix and $15.7 \% \beta$ - 


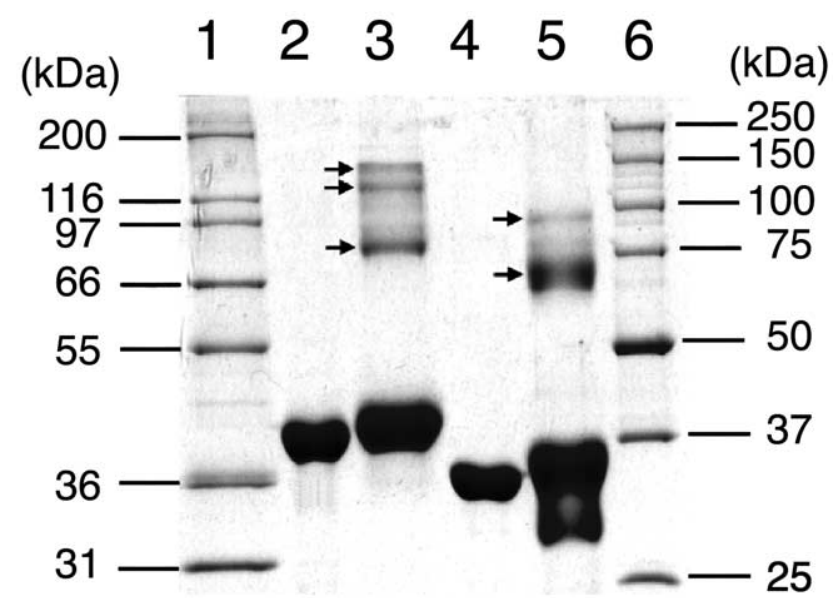

Fig. 4. SDS-PAGE of subunit cross-linking of sialic acid synthase and its $33 \mathrm{kDa}$ fragment with dimethyl suberimidate (DMS). Sialic acid synthase (NeuB-His ${ }^{6}$ ) and $33 \mathrm{kDa}$ fragment (NeuB33k-His ${ }^{6}$ ) at $1 \mathrm{mg} / \mathrm{ml}$ were separately subjected to chemical cross-linking experiments at $25^{\circ} \mathrm{C}$ for $2 \mathrm{~h}$ in the presence of $2 \mathrm{mM}$ DMS. Eight $\mu \mathrm{g}$ of each crosslinked protein was then applied to $10 \%$ gel for SDS-PAGE analysis. Lane 1, Mark12 wide range protein standards from Novel Experimental Technology (San Diego, CA); lane 2, untreated NeuB-His ${ }^{6}$; lane 3 , NeuB-His ${ }^{6}$ after cross-linking treatment, the arrows show the positions of tetramer, trimer, and dimer from top to bottom; lane 4, untreated NeuB33k-His ${ }^{6}$; lane 5, NeuB33k-His ${ }^{6}$ after cross-linking treatment, the arrows show the positions of trimer and dimer from top to bottom; and lane 6, Precision Protein Standards from Bio-Rad (Hercules, CA).

strand) is similar to KDO-8-P synthase (35.2\% $\alpha$-helix and $19.4 \% \beta$-strand) and sialic acid aldolase $(45.4 \% \alpha$ helix and $12.8 \% \beta$-strand) in the distributions of structural elements.

In summary, we demonstrated $E$. coli sialic acid synthase as a tetrameric protein, confirmed the cleavage of $E$. coli sialic acid synthase, and further identified the site-specific proteolysis at $\mathrm{Lys}^{280}$, leading to the formation of inactive 33 and $7 \mathrm{kDa}$ fragments. As the first investigation to examine the enzyme structure, the $C D$, MALDI-TOF-MS, and chemical cross-linking studies revealed that the fragmentation produced conspicuous changes in the content of the secondary and quaternary structures. Therefore, it is conceivable that after undergoing the specific cleavage mentioned above, the enzyme structure was changed from a tetramer to a trimer, resulting in the loss of activity.

Furthermore, the alignment of the last 144 amino acid residues (in the C-terminus) of $E$. coli $\mathrm{NeuB}$ with several homologs of different bacteria (including Streptococci agalactiae, Helicobacter pylori, Legionella pneumophila, Campylobacter jejuni, and N. meningitides) has shown that 28 residues are either identical or highly conserved ( $83 \%$ identical). It suggests that the C-terminal region of the enzyme should play an important role in catalytic activity or/and conformational integrity. Recently, Baardsnes and Davies [34] have demonstrated that type III antifreeze proteins are homologous
(36-40\% sequence identity) to the C-terminal region of mammalian sialic acid 9-phosphate synthase. The sequence length (63-66 amino acid residues) coincided unexpectedly with that of the cleaved C-terminal tail ( $7 \mathrm{kDa}$ fragment) of E. coli NeuB. X-ray crystallography and NMR studies both have confirmed that type III antifreeze proteins contain $\beta$-strand-rich structures [3537]. The results seem to be in accord with our $C D$ analysis that the truncation of $E$. coli NeuB with the Cterminal tail results in $9.7 \%$ decrease of $\beta$-strand. It is of interest to study further the role of the C-terminal $7 \mathrm{kDa}$ tail involved in enzyme activity, plus the significance of the specific single-site cleavage.

\section{Acknowledgments}

The work was supported by National Science Council (NSC-902113-M-001-028), National Health Research Institute (NSC-90-2323B-001-004), and Academia Sinica (Taipei, Taiwan). We are indebted to Prof. Shyh-Horng Chiou at the same institute for his critical reading of the manuscript and suggestions of $\mathrm{CD}$ and cross-linking experiments. We also thank Mr. Chuan-Fa Chang for graphic assistance.

\section{References}

[1] A. Varki, R. Cummings, J. Esko, H. Freeze, G. Hart, J. Marth, in: Essentials of Glycobiology, Cold Spring Harbor, New York, 1999, pp. 195-209 (Chapter 15).

[2] R. Schauer, S. Kelm, G. Reuter, P. Roggentin, L. Shaw, in: A. Rosenberg (Ed.), Biology of the Sialic Acids, Plenum, New York, 1995, pp. 7-16.

[3] K.E. Norman, A.G. Katopodis, G. Thoma, F. Kolbinger, A.E. Hicks, M.J. Cotter, G. Pockley, P. Hellewell, P-selectin glycoprotein ligand-1 supports rolling on E- and P-selectin in vivo, Blood 96 (2000) 3585-3591.

[4] E.C.M. Brinkman-Van der Linden, A. Varki, New aspects of siglec binding specificities, including the significance of fucosylation and of the sialyl-Tn epitope, J. Biol. Chem. 275 (2000) 86258632.

[5] Y.J. Kim, L. Borsig, H.-L. Han, N.M. Varki, A. Varki, Distinct selectin ligands on colon carcinoma mucins can mediate pathological interactions among platelets, leukocytes, and endothelium, Am. J. Pathol. 155 (1999) 461-472.

[6] A.P. Corfield, R. Schauer, in: R. Schauer (Ed.), Sialic Acids, Springer, New York, 1982, pp. 195-261.

[7] G. Taylor, Sialidases: structures, biological significance and therapeutic potential, Curr. Opin. Struct. Biol. 6 (1996) 830-837.

[8] K.N. Timmis, G.J. Boulnois, S.D. Bitter, F.C. Cabello, Surface components of Escherichia coli that mediate resistance to the bactericidal activities of serum and phagocytes, Curr. Top. Microbiol. Immunol. 118 (1985) 197-218.

[9] P.D. Rick, R.P. Silver, in: F.C. Neidhardt (Ed.), Escherichia coli and Salmonella: Cellular and Molecular Biology, American Society for Microbiology, Washington, DC, 1996, pp. 104-122.

[10] D. Bitter-Suermann, in: J. Roth, U. Rutishauser, F.A. Troy II (Eds.), Polysialic Acids: From Microbes to Man, Birkhauser Verlag, Basel, 1993, pp. 11-24.

[11] J.M. Bliss, R.P. Silver, Coating the surface: a model for expression of capsular polysialic acid in Escherichia coli K1, Mol. Microbiol. 21 (1996) 221-231.

[12] E. Vimr, S. Steenbergen, M. Cieslewicz, Biosynthesis of the polysialic acid capsule in Escherichia coli K1, J. Ind. Microbiol. 15 (1995) 352-360. 
[13] C. Whitfield, I.S. Roberts, Structure, assembly and regulation of expression of capsules in Escherichia coli, Mol. Microbiol. 31 (1999) 1307-1319.

[14] G. Zapata, J.M. Crowley, W.F. Vann, Sequence and expression of the Escherichia coli $\mathrm{K} 1$ neuC gene product, J. Bacteriol. 174 (1992) 315-319.

[15] P.W. Annunziato, L.F. Wright, W.F. Vann, R.P. Silver, Nucleotide sequence and genetic analysis of the neuD and neuB genes in region 2 of the polysialic acid gene cluster of Escherichia coli K1, J. Bacteriol. 177 (1995) 312-319.

[16] G.W. Jourdian, A.L. Swanson, D.R. Watson, S. Roseman, Isolation of sialic acid 9-phosphatase from human erythrocytes, J. Biol. Chem. 239 (1964) PC2714-PC2716.

[17] W. Kundig, S. Ghosh, S. Roseman, The sialic acids. VII. $N$-AcylD-mannosamine kinase from rat liver, J. Biol. Chem. 241 (1966) 5619-5626.

[18] D.R. Watson, G.W. Jourdian, S. Roseman, The sialic acids. VIII. Sialic acid 9-phosphate synthetase, J. Biol. Chem. 241 (1966) $5627-5636$.

[19] R. Stasche, S. Hinderlich, C. Weise, K. Effertz, L. Lucka, P. Moormann, W. Reutter, A bifunctional enzyme catalyzes the first two steps in $N$-acetylneuraminic acid biosynthesis of rat liver. Molecular cloning and functional expression of UDP- $N$-acetylglucosamine 2-epimerase/ $N$-acetylmannosamine kinase, J. Biol. Chem. 272 (1997) 24319-24324.

[20] S.M. Lawrence, K.A. Huddleston, L.R. Pitts, N. Nguyen, Y.C. Lee, W.F. Vann, T.A. Coleman, M.J. Betenbaugh, Cloning and expression of the human $N$-acetylneuraminic acid phosphate synthase gene with 2-keto-3-deoxy-D-glycero-D-galacto-nononic acid biosynthetic ability, J. Biol. Chem. 275 (2000) 17869-17877.

[21] D.G. Comb, S. Roseman, The sialic acids. I. The structure and enzymatic synthesis of $N$-acetylneuraminic acid, J. Biol. Chem. 235 (1960) 2529-2537.

[22] W.F. Vann, J.J. Tavarez, J. Crowley, E. Vimr, R.P. Silver, Purification and characterization of the Escherichia coli $\mathrm{K} 1$ neuB gene product $N$-acetylneuraminic acid synthetase, Glycobiology 7 (1997) 697-701.

[23] J. Sambrook, E.F. Fritsch, T. Maniatis, Molecular Cloning-A Laboratory Manual, second ed., Cold Spring Harbor, New York, 1989.

[24] L. Warren, The thiobarbituric acid assay of sialic acids, J. Biol. Chem. 234 (1959) 1971-1975.
[25] N. Sreerama, R.W. Woody, Estimation of protein secondary structure from circular dichroism spectra: comparison of CONTIN, SELCON, and CDSSTR methods with an expanded reference set, Anal. Biochem. 287 (2000) 252-260.

[26] N. Sreerama, S.Y. Venyaminov, R.W. Woody, Estimation of protein secondary structure from circular dichroism spectra: inclusion of denatured proteins with native proteins in the analysis, Anal. Biochem. 287 (2000) 243-251.

[27] G.E. Davies, G.R. Stark, Use of dimethyl suberimidate, a crosslinking reagent, in studying the subunit structure of oligomeric proteins, Proc. Natl. Acad. Sci. USA 66 (1970) 651-656.

[28] S.-H. Chiou, W.-P. Chang, H.-K. Lin, A re-evaluation of the molecular size of duck epsilon-crystallin and its comparison with avian lactate dehydrogenases, Biochem. Biophys. Acta 957 (1988) 313-317.

[29] A.S. Woods, J.C. Buchsbaum, T.A. Worrall, J.M. Berg, R.J. Cotter, Matrix-assisted laser desorption/ionization of noncovalently bound compounds, Anal. Chem. 67 (1995) 4462-4465.

[30] T.B. Farmer, R.M. Caprioli, Determination of protein-protein interactions by matrix-assisted laser desorption/ionization mass spectrometry, J. Mass Spectrom. 33 (1998) 697-704.

[31] A.S. Woods, M.A. Huestis, A study of peptide-peptide interaction by matrix-assisted laser desorption/ionization, J. Am. Soc. Mass Spectrom. 12 (2001) 88-96.

[32] T. Izard, M.C. Lawrence, R.L. Malby, G.G. Lilley, P.M. Colman, The three-dimensional structure of $\mathrm{N}$-acetylneuraminate lyase from Escherichia coli, Structure 2 (1994) 361-369.

[33] S. Radaev, P. Dastidar, M. Patel, R.W. Woodard, D.L. Gatti, Structure and mechanism of 3-deoxy-D-manno-octulosonate 8phosphate synthase, J. Biol. Chem. 275 (2000) 9476-9484.

[34] J. Baardsnes, P.L. Davies, Sialic acid synthase: the origin of fish type III antifreeze protein?, Trends Biochem. Sci. 26 (2001) 468-469.

[35] F.D. Sonnichsen, B.D. Sykes, H. Chao, P.L. Davies, The nonhelical structure of antifreeze protein type III, Science 259 (1993) 1154-1157.

[36] Z. Jia, C.I. Deluca, H. Chao, P.L. Davies, Structural basis for the binding of a globular antifreeze protein to ice, Nature 384 (1996) 285-288.

[37] A.A. Antson, D.J. Smith, D.I. Roper, S. Lewis, L.S.D. Caves, C.S. Verma, S.L. Buckley, P.J. Lillford, R.E. Hubbard, Understanding the mechanism of ice binding by type III antifreeze proteins, J. Mol. Biol. 305 (2001) 875-889. 